\title{
The Other Side of History: Underground Literature and the 1951 Waterfront Dispute
}

Patricia Thomas

Keywords: \#1951 waterfront dispute \#Emergency Regulations \#underground literature \#ephemera \#Max Bollinger

In February 1951, industrial discord between New Zealand watersiders and British ship-owners led to a dispute that was seen by each as a lockout and a strike respectively. Throughout the duration of the dispute, the Trades Union Congress and Wellington Waterside Workers' Union Action Committee produced and distributed substantial amounts of printed material to stiffen the struggle among its members, vilify strike-breakers and the National Government - whose ultimate aim it was to crush the Union - and to ridicule the police - who were the instruments of enforcement against the newly-minted Waterfront Strike Emergency Regulations. In defiance of Regulation 4(d), which banned the production and distribution of 'seditious' literature, a steady stream of illegal leaflets, pamphlets, lino-cut illustrations and cartoons emerged from the Gestetners and small presses in the homes of members and supporters of the watersiders. While printed material is touched upon in the documented examination of the dispute as a political and industrial struggle, it is never the focus of discussion. This article examines the multi-modal rhetoric of the underground literature to form a picture of one side of the story of what was, arguably, the most disruptive and divisive 151 days in the history of the New Zealand labour movement. 
As a means to empower those whose voices would not otherwise be heard, underground literature has long been a tool for protest, sedition and dissent. Its ephemeral nature and quotidian function often lead to its quick disposal.' If it survives it offers a rich source of evidence from which to build a narrative of history that differs from official histories; those versions of events usually filtered through traditional power bases. ${ }^{2}$ A selection of the underground literature related to the 1951 Waterfront Dispute is held in the Turnbull Library. ${ }^{3}$ These records, and the narratives they provide, would have been lost had it not been for the "pack rats of the New Zealand labour movement" who collected the material, kept it safe, and so made its acquisition by publicly-accessible institutions possible. ${ }^{4}$ There have been a number of written accounts of the dispute: accounts that approach it generally or specifically and from both sides. ${ }^{5}$ There are also oral histories that add the personal reflections of the participants: reflections that were recorded after the events of 1951. ${ }^{6}$ But, there has been little close attention paid to the underground literature produced at the time of those events, by the same participants.

This article explores how the multi-modality of this literature - the confluence of text, type and image - was used to maintain a position against "police thuggery, fascist regulations and the international pirates that called themselves ship-owners."7 Recognition of the value of multi-modal analysis of texts is fairly recent within linguistic and literary scholarship. ${ }^{8}$ It has directed our attention to the richer and more diverse possibilities of analysis that examines texts and images as corresponding parts of the same message. Lately, scholars have pointed also to the usefulness of understanding how type - the 'dress' of a text - contributes to the rhetoric of a message. ${ }^{9}$ Texts seen through this lens, and examined in conjunction with narrativelyconnected images, can reveal an expanded semantic network that further enhances the message. ${ }^{10}$ The article specifically examines how the Wellington Waterside Workers' Action Committee and the Trade Union Congress (TUC) used such multi-modal messaging to vilify and ridicule their adversaries during the most disruptive and divisive 151 days in the history of the New Zealand labour movement. ${ }^{11}$

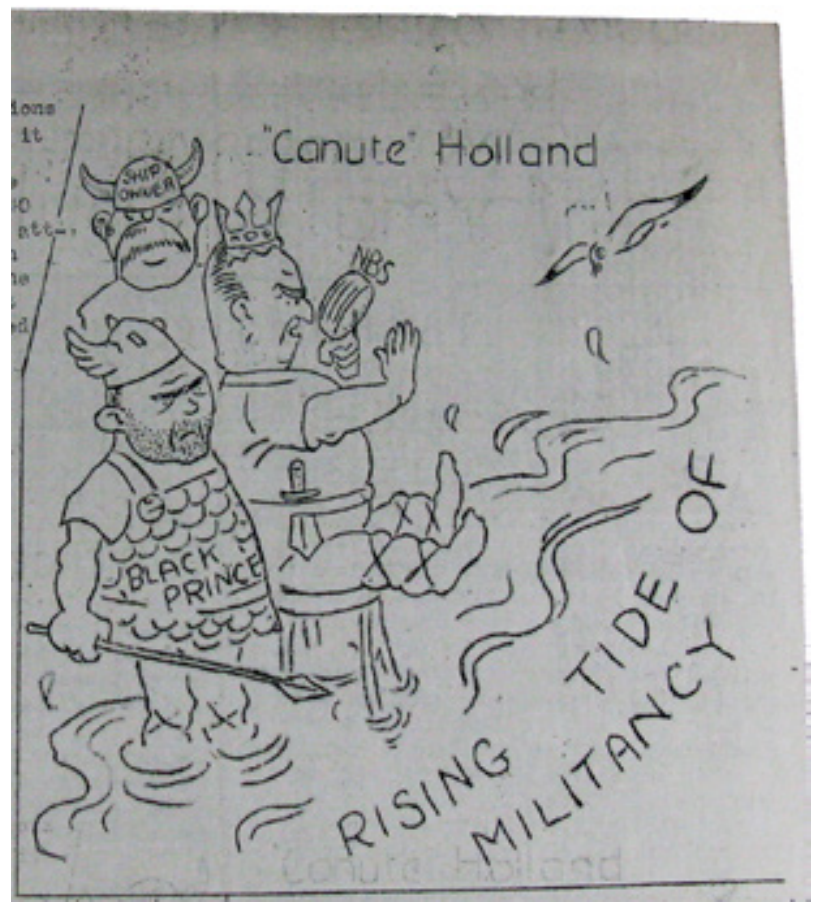

Figure 1: Max Bollinger, Holland 'Canute' attempting to hold back the rising tide of militancy. Wellington Watersiders' Official Bulletin 6 (detail), 27 March 1951. Herbert Roth papers, MSGroup-0314, Alexander Turnbul Library (0314 ATL).

\section{THE DISPUTE}

Melanie Nolan points out that the Dispute, which began on 15 February and ended on 15 July 1951, was as much political as it was industrial. ${ }^{12}$ Disputes over wages and conditions, and a struggle for control, were the catalysts for frequent antagonism between waterside workers and their employers (mostly British shipping companies) in the years immediately following the Second World War. The Federation of Labour (FoL) set up in 1937 to provide unity among disparate trade unions, sought to gain some control over decision-making through cooperation: a kind of soft socialism. ${ }^{13}$ It worked closely with the Labour Party, which was founded in 1916 as "largely, although not exclusively, a union party. ${ }^{114}$ The first Labour Government came into power in 1934, but by the 1940s, its working-class base was eroded as its membership and parliamentary representation progressively become more middle class. ${ }^{15}$ This had the effect of de-politicising the unions. The FoL became preoccupied with the "bread and butter" issues of day-to-day needs, rather than of union control over its own affairs. ${ }^{16}$ In the latter years of the 1940s, the New Zealand Waterside Workers' Union (NZWWU), along 
with the Carpenters', Miners', Tramwaymen's and Drivers' Unions, broke from the FoL and formed the more self-avowedly militant TUC. Rather than take cases to arbitration, a system put in place as a piece of antistrike legislation in the 1930s, it opted for direct negotiation. This was the situation in early 1951 when the NZWWU refused to work overtime - an action the ship-owners deemed a strike - and the shipping companies dismissed them - seen by the Union as a lockout. The issue became overtly political when the newly-elected National Government assumed control of the Dispute, welcoming the opportunity it presented to curb the Union's militancy and curtail its power. By weakening this strong Union, it hoped to rid the labour movement in general from what it saw as the influence of communism (Figure 1).

The FoL was alarmed at the militancy of the action and did not support the Union. Nor did the Labour Party, though it spoke against the Government's methods. This left the NZWWU and its supporting unions completely isolated.

\section{THE MATERIAL}

Due to its isolation, the Union was left with very little ammunition save "hurling words at the Tory attacks."17 Dick Scott, editor of the Transport Worker, estimated that the Action Committee distributed 650,000 bulletins, 400,000 pamphlets and an additional 400,000 miscellaneous pieces. Less than ten per cent was printed legally, resulting in over a million pieces of literature reaching readers through clandestine production and distribution networks. ${ }^{18}$ One of the pack rats, Rona Bailey, recalled that the diversity of people working at some time on the wharves provided a lode of capability available to swing into action when the time came to organise against the Government the police, the ship-owners and the mainstream press. ${ }^{19}$ Some could write, some were talented cartoonists, and others knew how to print. The most numerous and consistent among the productions were the Information Bulletins, produced two or three times a week in print runs of between 2000 and 9000 . Along with the text, edited and typed up by Chip Bailey, nearly every bulletin contained a cartoon by Max Bollinger. Neither Bailey nor Bollinger were watersiders; at the time, Bailey was a taxi driver and Bollinger, a freezing-worker. It was not until 1984, when he no longer needed to hide the fact, that he confirmed that it was he who produced upwards of a hundred cartoons for the bulletins and other assorted polemics. ${ }^{20}$ According to Bailey, the bulletins were "the only publication that brought, and still brings, the truth about the Wellington waterfront to the public." ${ }^{21}$ The Government labelled the Union's material "inflammatory, unbridled, scurrilous, poisonous, malignant, savage, filthy and foul." ${ }^{22}$

Rona Bailey thought that the bulletins were produced well, and generally they were, given the constraints under which they were produced. They were carefully designed with a consistent masthead and a hierarchy that directed readers to specific items and allowed for emphasis of any issue they addressed (Figure 2).

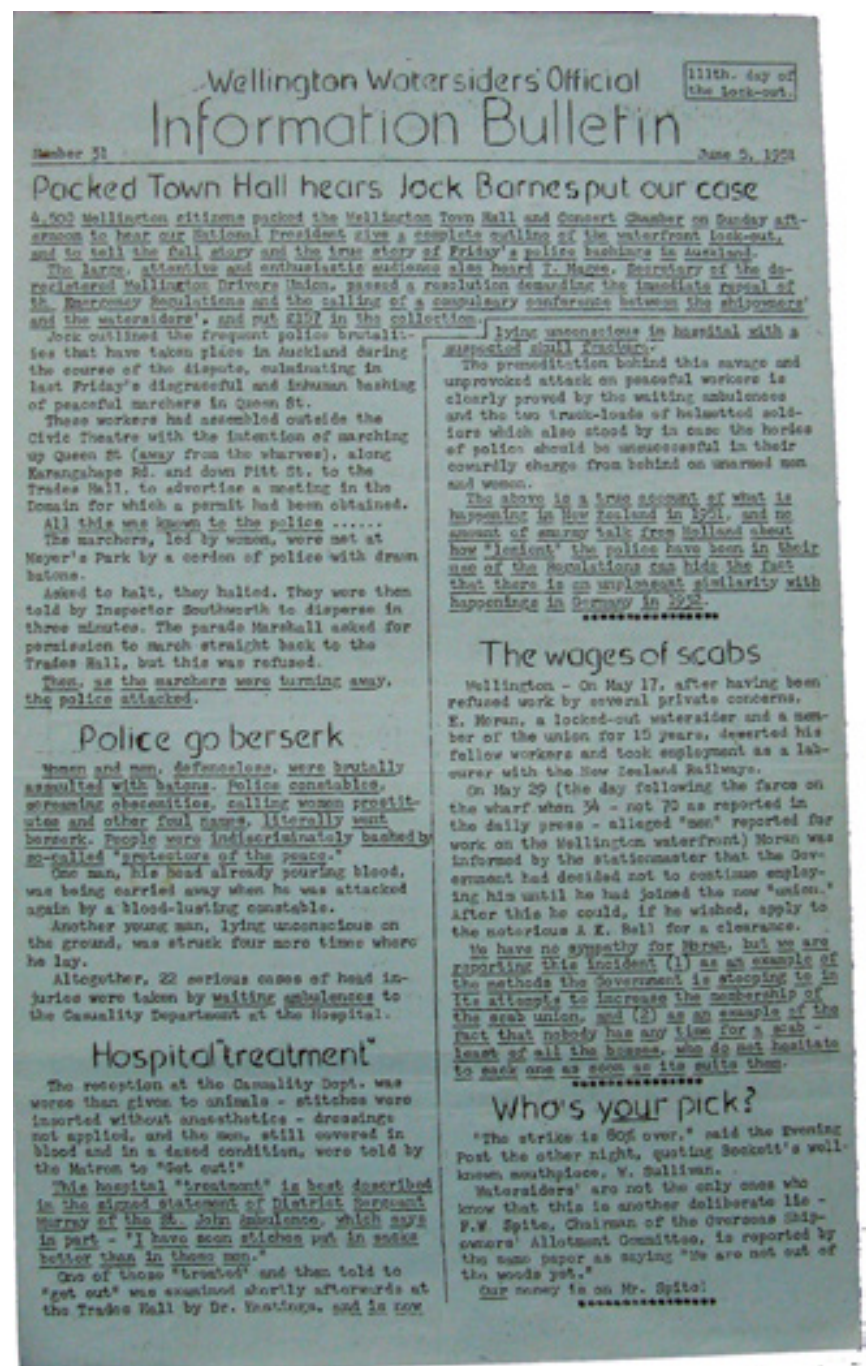

Figure 2: Wellington Watersiders' Official Bulletin 31,5 June 1951 . ATL. This demonstrates some attention to the detal of design, hierachy and visual emphasis. It is likely a first edition. It the saly bulletin in figure 12 which is dated 6 June 1951 and printed on different coloured paper. (0314 ATL). 
The characteristic handwritten lowercase ' $e$ ' that runs throughout all the issues suggests a single designing hand at work though whose it is, is unclear. The bulletins were printed on either quarto or foolscap paper of a variety of colours, which speaks to the contingent nature of supply. One shortage was remedied by the mysterious appearance of reams of paper from Government offices supplied, in an ironic twist, by their employees. ${ }^{23}$ The bulletins were printed, at times hurriedly, on a noisy Gestetner that moved from house to house. To avoid detection, it was operated in rooms that were neither close to the street nor to neighbours. Neither the equipment nor what it produced ever fell into the hands of the authorities who made considerable efforts to find them. Distribution was a multi-faceted and clandestine operation that used elaborate decoy manoeuvres. Each day, bulletins and other material were smuggled past the police on duty and into the Trades Hall for distribution through diversions and the friendly assistance of sympathetic supporters. Some were bus or taxi drivers, and others were irreproachable citizens whose identity Bollinger later noted would cause some surprise. ${ }^{24}$ So, why the need for such tactics?

\section{EMERGENCY REGULATIONS} were available to the Union throughout the dispute. Like the image in figure 6 , it pits the government against both the workers and New Zealand.

\section{SUPPRESSION}

There are two sides to every story but - only one appears in the Tory newspapers.

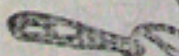
4. 90

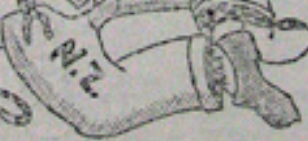

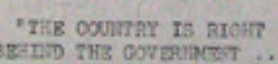

Figure 3. Wellington Watersiders' Officia Bulletin 41, 2 July 1951. (0314 AT) aid or abet a declared strike or the continuance of a declared

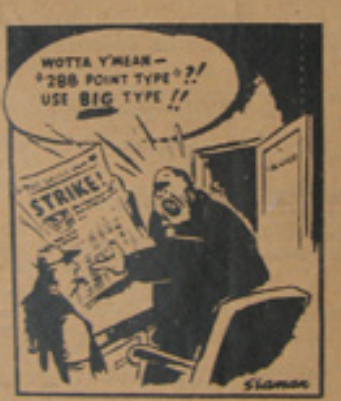

Yanh: Who not in mon listur?

Figure 4. Flyer printed for the Union by C.E. Rose \& Co. (0901 ATL).
Jacqueline Dickenson comments that is it not surprising that groups who line up against the power of the status quo are mistrustful and "riddled with insecurities." 25 The watersiders had good reason to be so. ${ }^{26}$ The anti-strike legislation that followed earlier industrial disputes dictated that funds could not be diverted to striking workers and that striking unions could suffer deregistration. In addition, the Waterfront Strike Emergency Regulations, set in motion without Parliamentary debate at the outset of the Dispute, closed down all the Union's conventional communication lines (Figures 3 and 4).

Specifically, it states that anyone commits an office against Regulation 4(d) if he or she

prints or publishes any statement, advertisement, or other matter that constitutes an offence against these regulations, or that is intended or likely to encourage, procure, incite, strike or that is a report of any such statement made by any other person. ${ }^{27}$

Distribution of such material was also subject to regulation with writing, carrying, displaying or causing to be written, carried or displayed an arrestable offence. The Union protested that this left workers no right of reply to the many accusations levelled against them and no legal or mainstream means to air their grievances. So, the protest went underground, and despite Regulation 13 [1] that forbad offensive or insulting words (images are not mentioned), the TUC and the Union fought back vociferously and immoderately. 


\section{FASCISTS, RATS AND SCABS}

The TUC's opening gambit labelled the Emergency Regulations "fascist" and "the most disturbing attack on the rights of individuals and trade unionists, as set out in the United Nations Charter of Human Rights, since the advent of Adolf Hitler." ${ }^{28}$ Much of this rhetoric was designed to push back at the public's endorsement of the Government whose platform of personal freedom and individual enterprise appealed to those weary of the collectivist years of Labour Government. ${ }^{29}$

Designed to stiffen the struggle and to gain support against what it deemed later to have been a barrage of lies and distortions broadcast through the "prostitute" press and radio, the Action Committee's references to Hitler and Fascism were a dominant trope throughout the material. ${ }^{30}$ Forcefully reminding readers of very recent events in their lives, they became probably the most offensive epithets the Union could raise to counter the actions of the Government and those, like the FoL vice-president Fintan Patrick Walsh, who supported its actions. The literature declared in a variety of ways that the Government was following in the footsteps of Hitler and Mussolini; that Fascism was alive and flourishing in New Zealand. ${ }^{31}$ For example, in June, the Minister of Works William Goosman said that the watersiders were worse than "transferable diseases" and that they needed to be dealt with. When told that Hitler talked that way, Goosman apparently replied "Hitler was right!" (Figure 5). The Union, its "comrades and womenfolk" vowed to fight with the same degree of "strength and fortitude" they demonstrated during the war.

The Committee suggested that Goosman's words warranted heeding by anyone whose sons gave their lives in the fight against Hitler. "He is a believer in Fascism! He thinks Hitler was right!" it shouts below the cartoon in Figure 5. ${ }^{32}$ The cartoon itself contains all the expected tropes: the marching lines of anonymous Stormtroopers, identifiable by their German helmets; a cheering and waving member of the public; swastikas along the route; and Goosman himself offering a Nazi-salute to the Prime Minister, Sid Holland. References in a variety of pamphlets mention Fascist methods, gas chambers, Japanese

Fascism, the Government that walks "in Hitler's steps", the "iron heels" of Hitler and the "outrageous lies" that were modelled on those of Hitler himself. At the same time, the Union declared that the Government also was beholden to Wall Street, and dupes of the war-mongering United States. It argued that the U.S. sought world domination, citing the Korean engagement as an example. Bollinger often conflated the

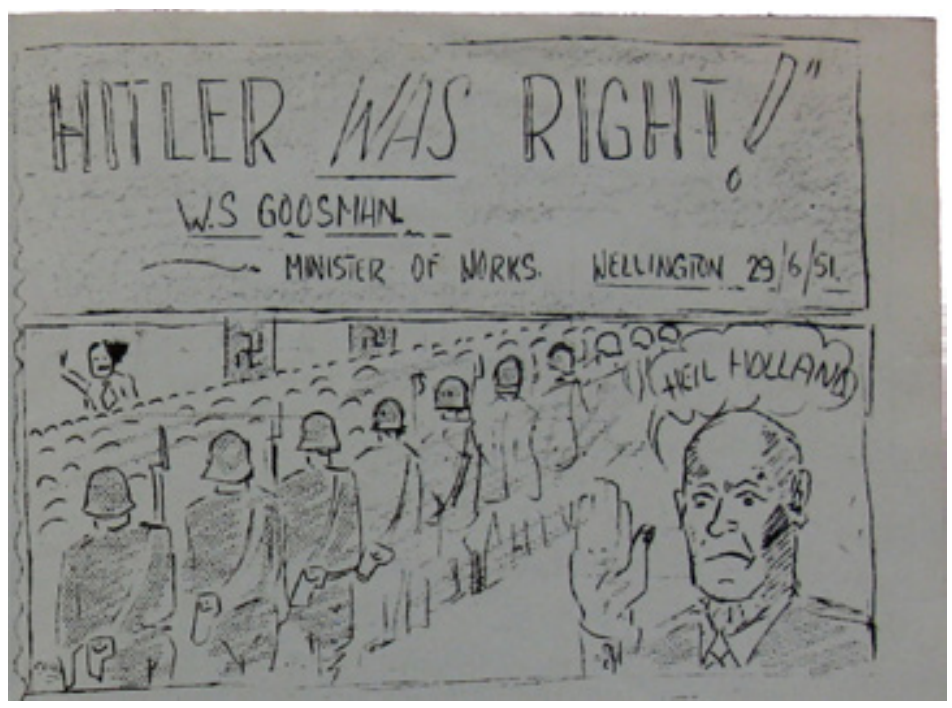

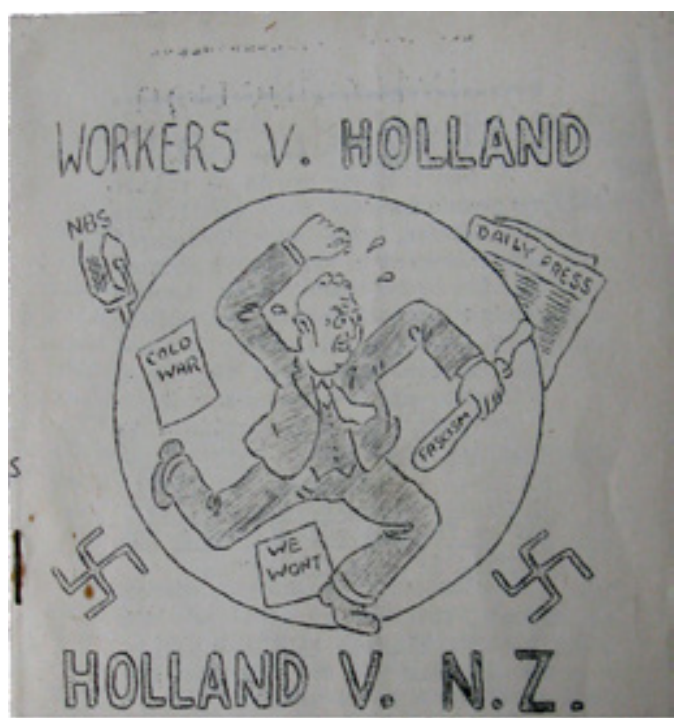

Figure 6: Max Bollinger. "Workers v Holland: Holland v. New Zealand". Pamphlet that pits Sid Holland against New Zealand workers and the country itself, with references to the Cold War, the mainstream communication networks and multi-modal references to fascism. (Roth papers/a).

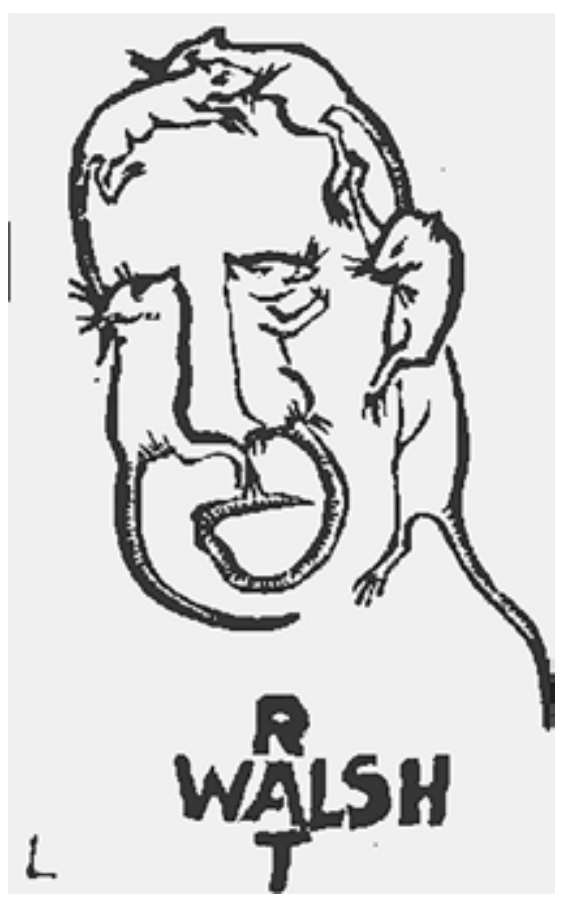

Figure 8: Len Gale. A caricature of Fintan patrick Walsh constructed from rats. Ministry for Culture and Heritage. 


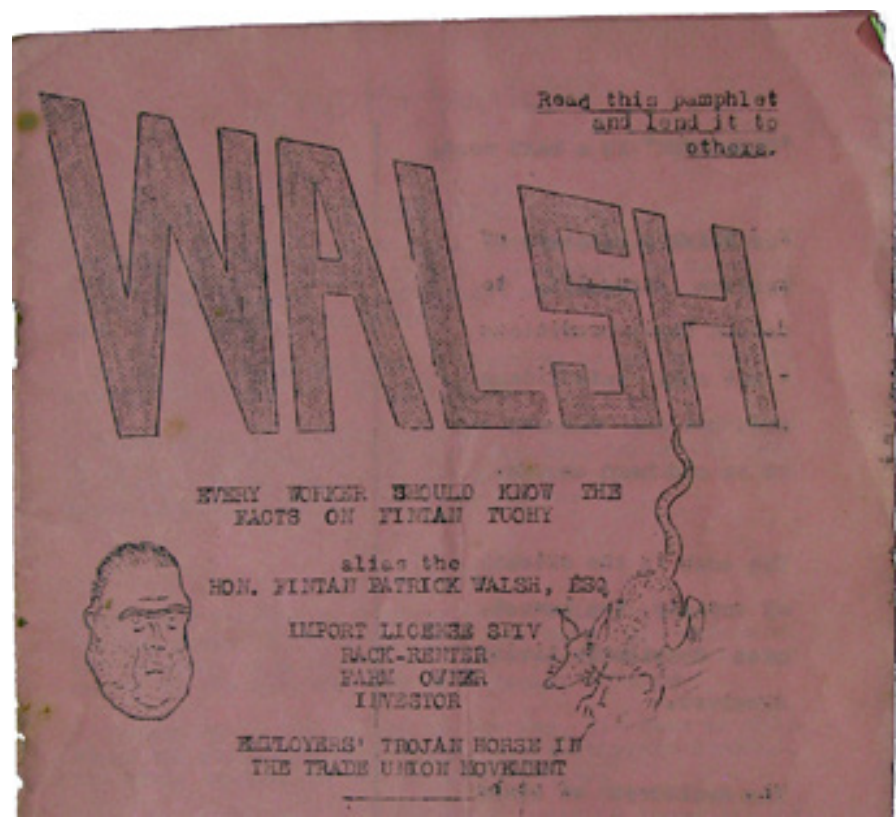

Figure 7: Max Bollinger. While the image again uses fascist through the rat and the list of Walsh's business activities ("Import licence Spiv, Rack(Import Licence Spiv, Rackrenter), on his lack of union (Roth papers/a).

interests of workers with those of New Zealand in this way. His cartoon in Figure 6, for example, contorts an image of Holland himself into the form of a swastika, which by then had come to signify malevolence.

The image casts Holland, the media, the Cold War and Fascism as both against workers and anti-New Zealand. ${ }^{33}$ Those who supported the Government's stance towards the dispute were equally vilified, and none more so than Walsh (Figure 7).

As President of the FoL, Walsh was an obvious target. The Action Committee painted him as a rat with Nazi connections. As the term used to describe a betrayer who abandons its colleagues, the rat has a long history, beginning with Shakespeare's reference to rats and sinking ships. But its characterisation is nuanced. Rather than an instrument of treachery against the working class, per se, the rat represents a betrayal of the ideal of working-class solidarity, and to some extent, of a shared ideal of manhood. ${ }^{34}$ Union solidarity, core to male-dominated industries, was seen as a respectable masculine activity. ${ }^{35}$ Auckland illustrator Len Gale's lino-cut pictures Walsh textually and visually as a group of rats (Figure 8 ).

The image de-humanises the FoL vice-president, renders him less than a man and more of the despicable animal that the Union argued he was. In another cartoon Bollinger articulated 'Walsh' as a

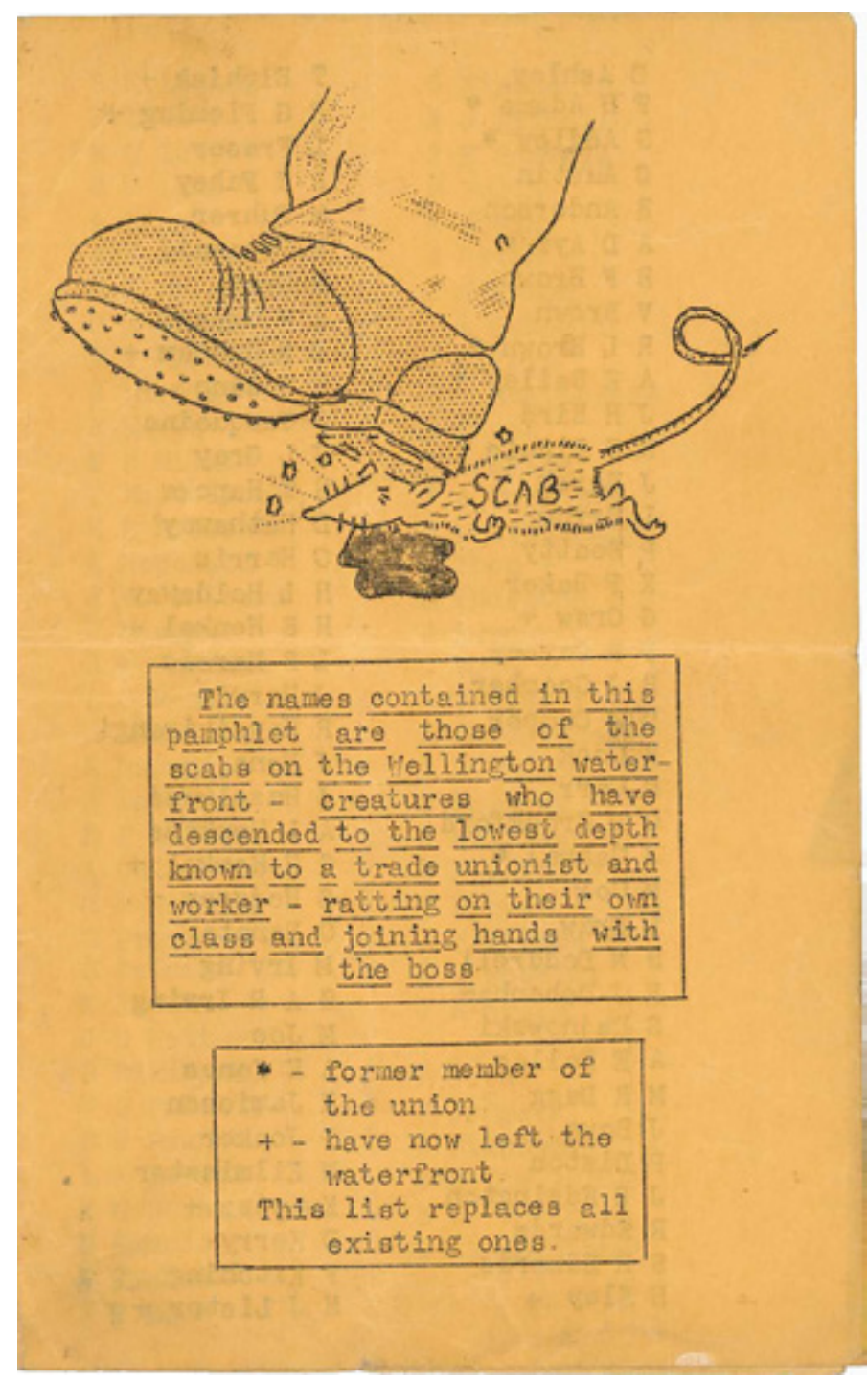

Figure 9: Max Bollinger. Scab; the names contained in this pamphlet are those of the scabs on the Wellington waterfront creatures who have descended to the lowest depth known to trade unionist and worker rating on their own class and jining hands with the boss. Fint cover of one of the many The 04-front. ATL. monumental pseudo-swastika, its verticals and horizontals resembling the symbol's dynamic arms. Walsh's face, a rat, and a reference to a Trojan Horse suggest a symbiotic relationship among them. In Figure 7 he is identified by his birth name of Tuohy. Another pamphlet emphasises his treachery, calling him a sooler-on (an attacker), grouping him with a snake (a metaphor for a treacherous person), a toad (understood as an Aesopean treacherous devil) and a snail. ${ }^{36}$ The rat epithet was not confined to Walsh. Along with scab, it became a multi-modal way of speaking of strike-breakers. 


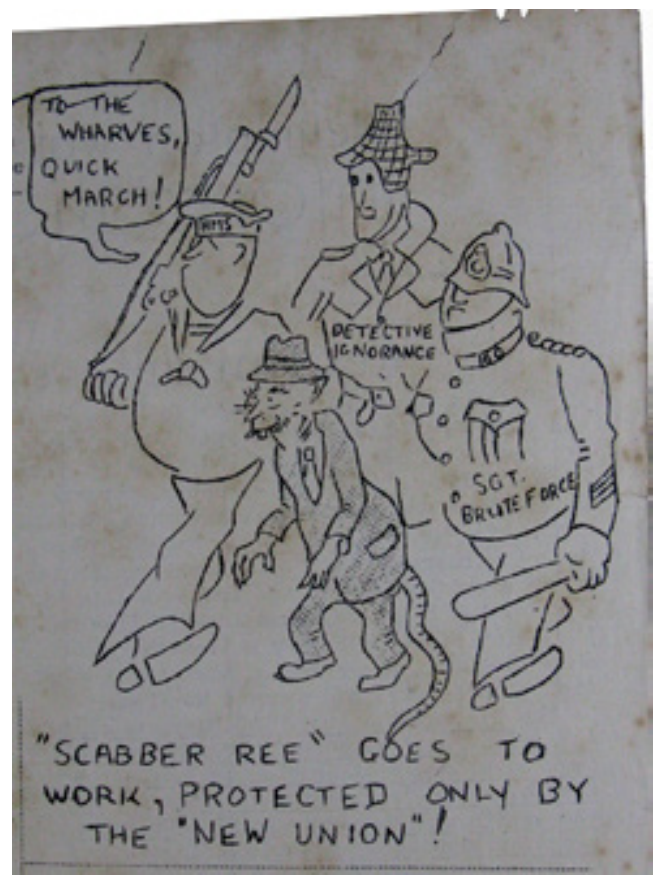

Figure 10: Max Bollinger. Scab labour in the form of a rat and less than a man being escorted

Wellington Watersiders' Official Bulletin 26, 21 May 1951. (0314 ATL).
In the eyes of the Union, a scab was a creature made from some "awful substance" left over after the making of the toad, the snake and the snail. It had a "cork-screw soul, a water-sogged brain and a combination backbone made of jelly and glue." ${ }^{137}$ Physically, it is material that forms over a wound, but has come to represent a morally disfiguring disease in union rhetoric. A scab was seen as a greater enemy than employers or the governments. ${ }^{38}$ At a time when physical labour could be hard and dangerous, brotherhood was crucial. 'Scab' is visited upon those who threaten the solidarity of labour by not standing shoulder to shoulder with their brothers. Some unionists were fined and even imprisoned for hurling this "ultimate in insulting language" at their adversaries. ${ }^{39}$ There is little way to picture a scab and while the name remains in texts, the rat was more often how it was articulated visually. The Union produced scab lists that divulged the names and addresses of strike-breakers, one of which is illustrated with a large workman's boot crushing a rat beneath its heel - "the names listed in this pamphlet are those of the creatures at present befouling the Wellington waterfront - when we pass an open sewer we will remember them" (Figure 9).
Scabs came largely in the form of men recruited or 'herded' for waterside work, men who were enticed, against Union pleas, into forming a new union after the NZWWU was deregistered. In Figure 10, Bollinger depicts a scab/rat accompanied to work by the 'brute force' of the Government's enforcement tools. Many such men were protected by police cordons as they made their way past the unionists to the wharves. One of the most ingenious pieces of pamphleteering against scabbery was perpetrated by workers in the Government Printing Office. Using an official Department of Health illustration of a rat in a leaflet that warned against the industrial diseases brought by vermin, they over-printed across it "Don't scab" and issued it in thousands of copies. ${ }^{40}$ While some adversaries were vilified as scabs and rats, the police were ridiculed. This is especially evident in Bollinger's cartoons.

\section{VICTIMS OF POLICE BRUTALITY}

The sheer volume, and the apparent effect, of the literature that issued from the Action Committee's Gestetners and the TUC's presses made enforcing the Regulations against it a priority. While the mainstream press reported the "reign of terror" perpetrated by the "Communistinspired dock workers," Bollinger illustrated the other side. ${ }^{41} \mathrm{His}$ wryly humorous cartoons spoke of the "victims of police brutality", illegal searches and the targeting of women and children. ${ }^{42}$ Under Section 18[b] of the Regulations, a police officer in pursuit of evidence of a suspected offence against the Regulations was allowed to enter "land, premises or place" or arrest any person. ${ }^{43}$ Looking for the tools of the illegal literature, plainclothes police raided "and ransacked" homes, often without warrants and late at night. ${ }^{44}$ Bollinger's depiction of this obviously goes beyond what the police were even likely to do, but it highlights the perceived ridiculousness of the police response (Figure 11).

"Do you hear the tramp of Holland's jackbooted Stormtroopers invading the privacy of your homes in the dead of night?" asks a pamphlet produced by the TUC. ${ }^{45}$ Even while the Government was arguing for the lenient position taken by the police, the cartoon in Figure 12 gainsays Holland's words by suggesting the police physically attacked women. The image in Figure 13 again ridicules police actions through an exaggerated response to the participation of watersiders' families in the distribution of their literature. 
Another route the Action Committee took to garner support and vilify the enemy was to link the present struggle with similar historical events. The image in Figure 14 was one among a number of discursive narratives created to remind people that this experience was one of a long line of working-class struggles including the Great Strike of 1913 and the 1932 Queen Street riots. ${ }^{46}$

It might equally have gone further back to evoke the Maritime Strike of 1890 . It too began on the wharves and spread to other unions, and it too found itself ranged against ship-owners and the government. So, while the 1951 experience was not a new one, it was a bruising one that ultimately saw the end of the NZWWU.
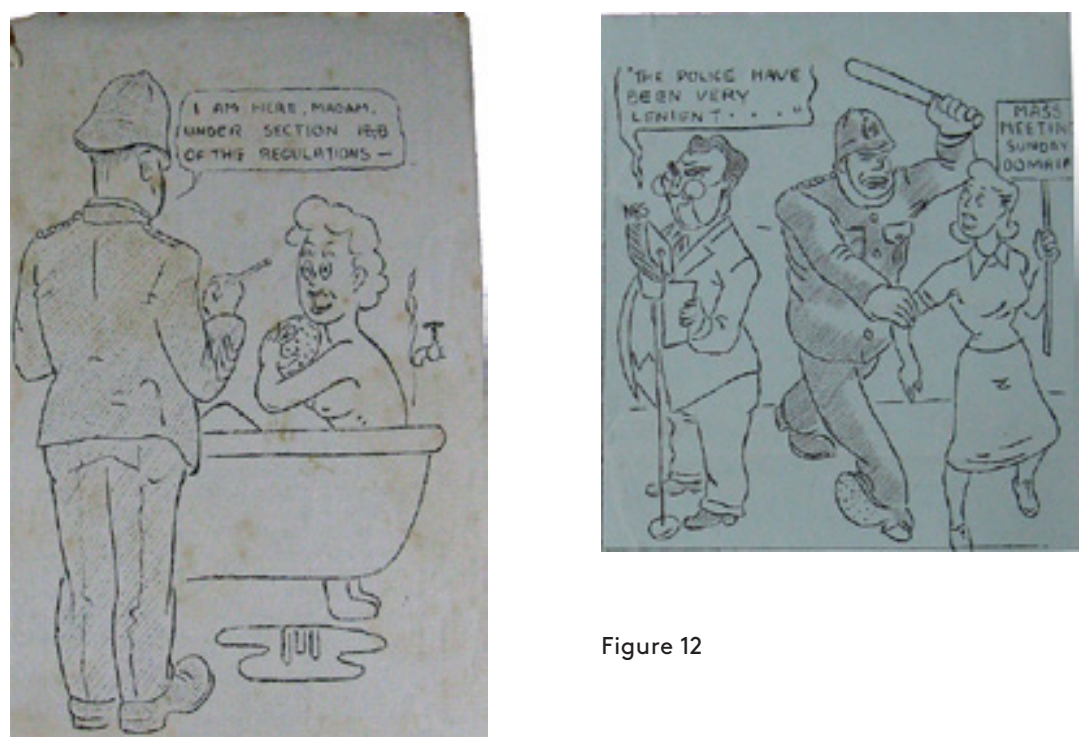

Figure 12

Figure 11
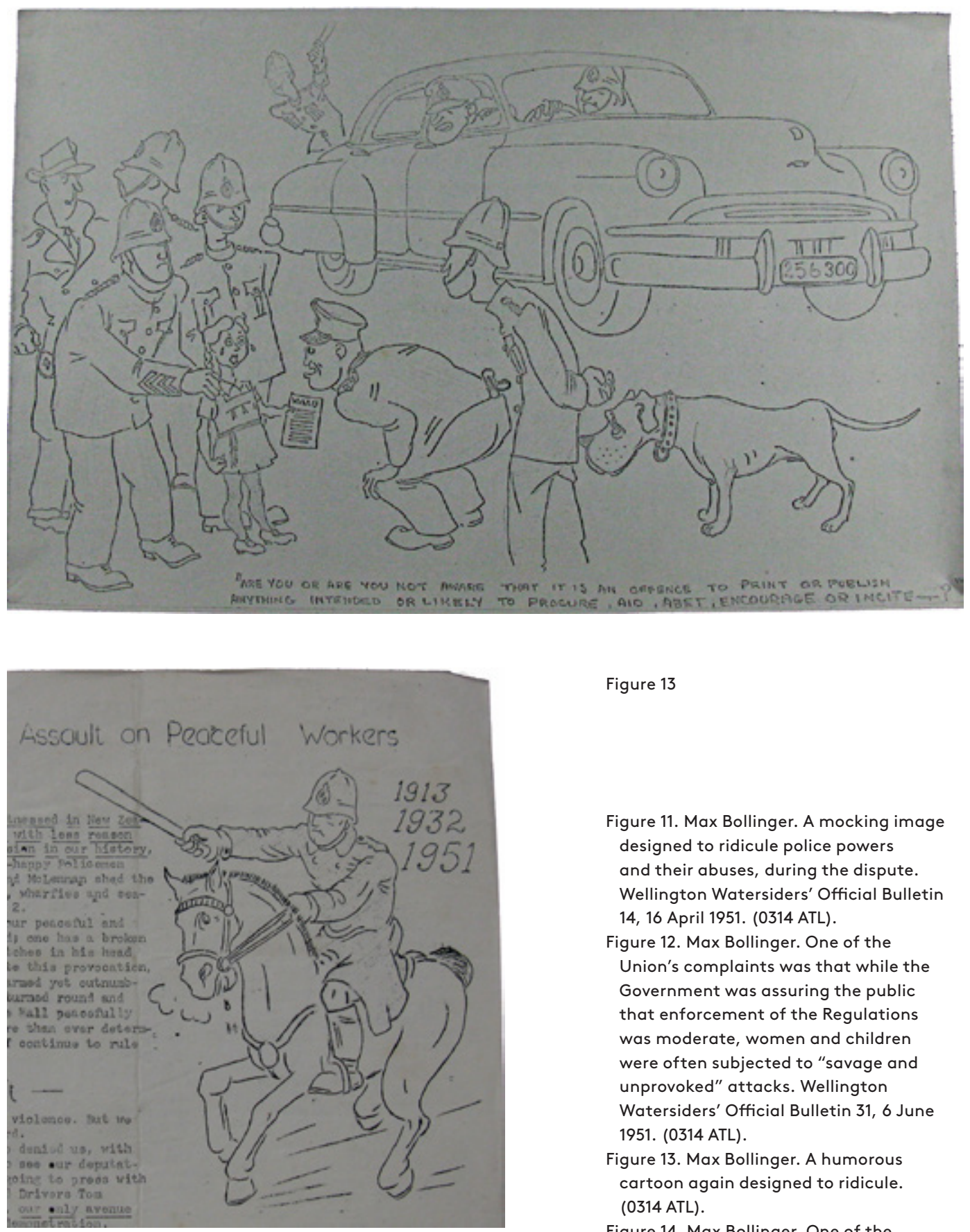

Figure 14
Figure 13

Figure 11. Max Bollinger. A mocking image designed to ridicule police powers and their abuses, during the dispute. Wulle 14, 16 April 1951. (0314 ATL). Union's complaints was that while the Government was assuring the public that enforcement of the Regulations was moderate, women and children were often subjected to "savage and unprovoked" attacks. Wellington Watersiders' Official Bulletin 31, 6 June 1951. (0314 ATL).

Figure 13. Max Bollinger. A humorous cartoon again designed to ridicule. (0314 ATL).

igure 14. Max Bollinger. One of the tactics used to gain support was to remind people that the present struggle against tyranny was part of a long and on-going battle for workers' rights. Wellington Watersiders' Official Bulletin 18, 2 May 1951. (0314 ATL). gure 12. Max Bollinger. One of the 


\section{CONCLUSION}

By the production of Bulletin 35, the Committee was resolved to continue the struggle in spite of reducing numbers remaining loyal. For many, the situation had become untenable. Some watersiders felt financially obliged to take work in other industries; many of the support strikes went back to work. The Government was unmoveable. Having put strike-breakers and the armed services to work on the wharves, it saw no need to give in. And it didn't. On 15 July, the Union conceded defeat. A newspaper report noted that there would be no more anonymous strike pamphlets beyond the last, number 43 . They were wrong.

Buoyed by their success in breaking the strike, the Government called an early election. The Action Committee then set out to think about the future of unionism on the wharves and to campaign against the National Party in the election. It continued to fight through the medium of the bulletins, but, in the end, the National Party retained its majority. The toll on Union members was heavy. The dispute cost jobs and exacted misery on thousands. Weaker unions replaced the once-strong Union, the Labour Party struggled to gain purchase within the electorate, and the cause of unionism was set back for years

afterwards. The struggle was always going to be hopeless given its time in history, the resolve of a strong government and the support of the public. But what the underground literature has produced is a picture of the inside of the struggle, some the issues and concerns of those who supported it as it played out over the 151 days. And in retrospect, as the editor of the 1960s/70s underground magazine Cock, Chris Wheeler, points out, the material demonstrates "what could be done with a simple little printing press [sic] hidden away in someone's basement." ${ }^{147}$

\section{ENDNOTES}

1 Maurice Rickards, Encyclopedia of Ephemera: A Guide to the Fragmentary Documents of Everyday Life for the Collector, Curator and Historian, ed. Michael Twyman (New York: Routledge, 2000).

2 Anna Green, "Go-Slows, Gliding Away and Theft: Informal Control Over Work on the New Zealand Waterfront 1915-1951," Labour History 63 (1992); The Government version of the Dispute was documented in the mainstream media and can now be seen through police files made available in 2008 .

3 The genesis of this paper is in a small publication I contributed to as an adjunct to the Trade Union History Project's 2001 exhibition "Lockout 51", to commemorate the 50th anniversary of the dispute. I use 'dispute' to reflect my intention to use a term that is as neutral as it can be.

4 Grace Millar, "Families and the $1951 \mathrm{New}$ Zealand Waterfront Lockout" (PhD thesis, Victoria University, 2013), ii.

5 Dick Scott, 151 Days: History of the Great Waterfront Lockout and Supporting Strikes, February 15-July15 1951 (Auckland: Southern Cross Books, 1954); Rona Bailey, "1951 The

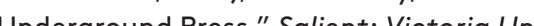
Underground Press," Salient: Victoria University Student Newspaper, 34.18, October 6 1970; Michael Bassett, Confrontation '51: Th 1951 Waterfront Dispute (Wellington, Reed, 1972); Jock Barnes, Never a White Flag: The Memoirs of Jock Barnes, Waterfront Leader, ed. Tom Bramble (Victoria University Press, Wellington, 1998); David Grant (ed). The Big Blue: Snapshots of the 1951 Waterfront Lockout (Canterbury University Press, Christchurch, 2004); Anna Green, British Capital, church, 2004); Anna Green, British Capital, Waterfront, 1915-1951 (Dunedin: University of Otago Press, 2001); Millar, "Families".

6 Among those specific to this article are: "The 1951 Waterfront Disupte with Max Bollinger and Dick Scott," Ref. OHLC-005737; and "Interview with Rona Bailey," Kerry Taylor, OHInt-0861092.Alexander Turnbull Library, Wellington

Wellington;
Barnes, Never, 190

8 For theoretical discussions of the value of understanding text as multi-modal, see Gunther Kress, \& Theo van Leeuwen, Multi- modal Discourse: the Modes and Media of Contemporary Communication (London: Arnold, 2001); Theo van Leeuwen, "Ten Reasons Why Linguists Should Pay Attention to Visual Communication," in Discourse and Technology: Multimodal Discourse Analysis, ed. Philip Levine and Ronald Scollon (Washington: Georgetown University Press, 2004): Giorgia Aiello, "Theoretical Advances in

Critical Visual Analysis: Perceptions, Ideology, Mythologies and Social Semiotics." Visual Literacy, 26.2 (2006); David Machin, Introduction to Multimodal Analysis (London: Hodder Arnold, 2007); and Jürgen Spitzmüller, 'Visible by Design: The Significance of Typography in Media Communication', Working Group for Language and Media Studies (Tokyo, Nihon University, 2 March 2007).

9 Terry L. Childers \& Jeffrey Jass, "All Dressed Up with Something to Say: Effects of Typeface Semantic Associations on Brand Perceptions and Consumer Memory." Journal of Consumer Psychology, 12.2 (2002); See also Hartmut Stöckl, "Typography: Body and Dress of a Text - a Signing Mode between Language and Image." Visual Communication, 4.2 (2005).

10 Inger Lassen, Jeanne Strunck and Torben Vestergaard, eds, Mediating Ideology in Text and Image: Ten Critical Studies (Amsterdam John Benjamens Publishing, 2006)

11 Toby Boraman notes that the NZWWU president, Jock Barnes, had a strong syndicalist philosophy. Syndicalism emerged in New Zealand prior to the 1913 General Strike, evaded the softening labour stance, and arose aga in 1951. This gaveur stance, and arose again in 1951. This gave an anarchical flavour to the more militant unions. Toby Boraman, Rabble Rouser and Merry Pranksters: A History of Anarchism in Aotearoa/New Zealand from the Mid-1950s to the Early 1980s, 2nd ed (Christchurch: Katipo Books and Irrecuperable Press, 2008).

12 Melanie Nolan, "'The Women were Bloody Marvellous': 1951, Gender and New Zealand Industrial Relations," Historical Studies in Industrial Relations 16 (2003).

13 Douglas C. Webber, "Trade Unions, the Labour Party and the Death of Working-class Politics in New Zealand' (MA thesis, University of Canterbury, 1976), fn 30, 77. 
14 Webber, "Trade Unions", 3; see also John A. Lee, Socialism in New Zealand (London: T. Wener Laurie, 1938); Peter Franks \& Melanie Nolan, eds, Unions in Common Cause: The New Zealand Federation of Labour 1937-88 (Wellington: Steel Roberts, 2011).

15 Webber, "Trade Unions," 3.

16 Webber, "Trade Unions," 72 \& 70.

17 Trade Union Congress, Flyer "Mass Action!" (Auckland: Forward Press, June 1951). Alexander Turnbull Library (hereafter ATL). Herbert Otto Roth papers, 94-106-10/06 (hereafter Roth papers/a).

18 Dick Scott quoted in Bailey, "Underground Press," 9

19 Bailey, "Underground Press," 9

20 Noel Hilliard, "The Man behind Those..." Evening Post, July 9, 1984.

21 Wellington Watersiders' Official Bulletin, 50, August 19, 1951. ATL, MS-Group-0314.

22 Scott quoted in Bailey, "Underground Press," 9.

23 Bailey, "Underground Press," 12

24 Bollinger in Hilliard "The Man."

25 Jacqueline Dickenson, "'Chasing the Rat': The Language of Betrayal in Britain and Australia," Labour History Review 68.2 (2013): 163.

26 Gavin Ellis, Complacent Nation (Wellington: Bridget Williams Books, 2016).

27 New Zealand Government, Waterfront Strike Emergency Regulation 1951, accessed 14 October 2016, http://www.nzlii.org/nz/legis/ num_reg/wser1951422/

28 Combined Trade Unon Committee, Pamphlet, "A Call to All New Zealanders" (Auckland,

1952). ATL. Roth papers/a, folder 1.

29 Redmer Yska, "Spies, Lies and Red Herrings," in The Big Blue: Snapshots of the 1951 Waterfront Lockout, ed. David Grant (Canterbury University Press, Christchurch, 2004).

30 Combined Trade Unon Committee, "A Call": Wellington Watersiders' Action Committee, “The Lockout of ' 51, , Wellington Watersiders'
Information Bulletin, 17, April 27, 1951. ATL, MS-Group-0314.

31 Barnes, Never, 170

32 Anon, "NZ Can Go to Hell", Roth papers/a.

33 "Workers V. Holland: A Report to Unionts on the Situation Today with an Appendix giving the Experience of Workers Overseas under the Same Fascist Attack." Pamphlet. Early Bird Press, 1951. ATL, P Box 331.8922 WOR.

34 Dickenson, "'Chasing the Rat, "' 175.

35 Millar, "Families," 8.

36 Dick Scott, "If it's Treachery, Get Tuohy!" Pamphlet. ATL, P Box 920 WAL 1951. Snails seem to have no connection to treachy except inasmuch as an anonymous blogger except inasmuch as an anonymous blogger
suggests they, being perceived as French, were seen by the British as disloyal. Accessed September 22, 2017, http://www. gatesofcamelot.net/forums/archive. php?forum_id=2\&thread_id=2309\&low $=0$.

37 "The Scab," Pamphlet. ATL, Scott Papers, MS Papers-8572-38.

38 Bruce Scates, "Mobilizing Manhood: Gender and the Great Strike in Australia and Aotearoa/New Zealand," Gender \& History 9.2 (1997).

39 Barnes, Never, 199.

40 Bailey, "Underground Press," 12.

41 Quoted in Scott, 151 Days, 111. There is no evidence that either the president of the Union, Jock Barnes, or its secretary, Toby Hill, had any affiliation with the communist party. This is in contrast to Walsh who had been a

42 "22 Peaceful Workers Injured by Police." Jun 1, 1951. Flyer. ATL. Roth papers/a.

43 Barnes, Never, 170

44 Bailey, "Underground Press," 9.

45 TUC, "Mass Action."

46 Dickenson, "Chasing the Rat," 165.

47 Chris Wheeler, quoted In Bonaman, Rabble Rousers, 55 